\title{
Kandungan Pigmen dan Aktivitas Antioksidan pada Tanaman Celosia plumosa Bunga Merah dan Kuning
}

\section{The Pigment Contents and The Antioxidant Activity from Red and Yellow of Celosia plumosa Plant}

\author{
Dewi Prabawaningrum, Sri Kasmiyati*, Anggara Mahardika \\ Program Studi Biologi Fakultas Biologi Universitas Kristen Satya Wacana \\ *Email: kas@uksw.edu
}

Diterima 9 Mei 2020 / Disetujui 24 Juli 2020

\begin{abstract}
ABSTRAK
Tanaman Celosia plumosa memiliki variasi warna yang ditentukan oleh kandungan pigmen. Aktivitas antioksidan memiliki senyawa yang mampu memperlambat proses oksidasi. Penelitian ini bertujuan untuk mengetahui kandungan pigmen (klorofil, karotenoid, dan antosianin), flavonoid, fenolik, dan aktivitas antioksidan pada tanaman C.plumosa bunga merah dan kuning dengan variasi organ daun dan bunga. Analisis kandungan klorofil dan karotenoid dengan spektrofotometri, antosianin dengan $\mathrm{pH}$-diferensial, flavonoid dengan $\mathrm{AlCl}_{3}$ (kolorimetri), fenolik dengan Folin-ciocalteau, dan aktivitas antioksidan dengan DPPH. Kandungan klorofil tertinggi pada daun bunga kuning sebesar 128,80 $\mu \mathrm{g} / \mathrm{ml}$. Kandungan karotenoid tertinggi pada bunga merah sebesar $8,27 \mathrm{mg} / \mathrm{ml}$. Kandungan antosianin tertinggi pada bunga merah sebesar $28,94 \mathrm{mg} / \mathrm{gr}$. Flavonoid tertinggi pada bunga merah sebesar 5,60 mg/L. Fenolik tertinggi pada bunga merah sebesar 3,48 $\mathrm{mg} / \mathrm{L}$. Nilai $\mathrm{IC}_{50}$ tertinggi ditemukan pada bunga merah sebesar $2,75 \mathrm{ppm}$. Bunga merah memiliki kandungan pigmen antosianin dan karotenoid yang tinggi, dan didukung dengan metabolit sekunder flavonoid dan fenolik yang tinggi. Pada bunga merah kandungan pigmen karotenoid dengan flavonoid terdapat korelasi positif. Sedangkan pada daun bunga kuning dan merah tidak ada korelasi antara flavonoid dan pigmen. Pada daun bunga kuning terdapat korelasi positif antara pigmen antosianin dengan flavonoid yang kuat.
\end{abstract}

Kata kunci : antioksidan, Celosia plumosa, flavonoid, fenolik, pigmen.

\begin{abstract}
Celosia plumosa plants have a variety colors defend of the pigments. The antioxidant activity have a compounds to slowdown oxidative process. This research aims to determine the pigments (chlorophyll, carotenoid, anthocyanin), flavonoid, phenolic and the antioxidant activity of red and yellow flower C.plumosa plant with the variation of leave and flower. Spectrophotometry used to analysis chlorophyll and carotenoid contents. Antosianin used $\mathrm{pH}$-differential. Flavonoid used $\mathrm{AlCl}_{3}$ (colorimetry). Phenolic used folin-ciocalteu and antioxidant activity used DPPH. The highest chlorophyll contents of yellow flowers amount to $128,80 \mu \mathrm{g} / \mathrm{ml}$. The highest carotenoid contents red flowers amount $8,27 \mathrm{mg} / \mathrm{ml}$. The highest antosianin contents of red flowers amount $28,94 \mathrm{mg} / \mathrm{gr}$. The highest flavonoid of red flowers amount $5,60 \mathrm{mg} / \mathrm{l}$. The highest phenolic of red flower amount $3,48 \mathrm{mg} / \mathrm{L}$. The highest value of $\mathrm{IC}_{50}$ have found from the red flowers amount $2,75 \mathrm{ppm}$. The red flower has the highest anthocyanin and carotenoid pigments, and supported by high secondary metabolic of flavonoid and phenolic. In the pigment contents and secondary metabolic of the red flower have a positive correlation between carotenoid and flavonoid. While at the flavonoid and the pigments of yellow and red flower leaves have no correlation. At the yellow flower leaves have a strong positive correlation between antosianin pigments and flavonoid.
\end{abstract}

Keywords : antioxidant, Celosia plumosa, phenolic, flavonoid, pigment. 


\section{PENDAHULUAN}

Tanaman celosia memiliki kelimpahan yang cukup besar dan lebih banyak digunakan sebagai tanaman hias hamparan dan tanaman hias pot, yang diminati karena keunikan pada bentuk, warna dan coraknya (Mastuti et al., 2013). Berdasarkan penelitian sebelumnya pada tanaman celosia memiliki total kandungan klorofil yang ditemukan pada daun dalam mengitensifikasi warna hijau dan pada tanaman celosia memiliki karotenoid maksimum yang menyebabkan peningkatan akumulasi komponen seperti klorofil dan karoten (Aparna et al., 2017). Antosianin merupakan pigmen yang dapat larut dalam air yang menyebabkan terjadinya warna merah, ungu, dan biru. Antosianin juga sebagai zat warna yang bersifat polar dan akan larut dengan baik pada pelarut yang bersifat polar. Berdasarkan penelitian yang sudah dilakukan bahwa tanaman celosia memiliki potensial tinggi untuk produksi antosianin dan dalam uji aktivitas antioksidan menggunakan DPPH menunjukkan memiliki khasiat antioksidan khas pada asam askorbat (Mohajer S et al., 2014).Selain itu, berdasarkan penelitian sebelumnya pada ekstrak daun memiliki senyawa asam fenolik dan flavonoid yang ditemukan pada daun celosia yang memiliki efek biologis, termasuk aktivitas antioksidan (Urmila et al., 2013). Serta dengan menggunakan DPPH menunjukkan adanya aktivitas antiokisdan (Urmila et al., 2013).

Senyawa dalam kelompok fenolik yang berperan sebagai antioksidan karena senyawa fenolik memiliki aktivitas sebagai agen pereduksi, donor hidrogen dan penghilang oksigen tunggal. Selain fenolik, flavonoid juga memiliki kemampuan dalam mereduksi radikal bebas (Giorgio, 2000). Serta antioksidan dapat menghambat oksigen reaktif atau nitrogen reaktif (Elka, dkk., 2012). Pada penelitian sebelumnya sudah dilakukan pengujian mengenai kandungan senyawa pigmen (klorofil, karotenoid, dan antosianin) (Aparna et al., 2017 \& Mohajer S et al., 2014), flavonoid, fenolik, dan aktivitas antioksidan pada tanaman Celosia argentea dan Celosia cristata dengan menggunakan organ daun (Urmila et al., 2013).

Berdasarkan penelitian yang dilakukan sebelumnya, peneliti mengembangkan penelitian dengan menggunakan tanaman Celosia plumosa denngan membandingkan kandungan dan aktivitas antioksidan dari organ tanaman Celosia plumosa yaitu bunga dan daun. Kandungan komponen yang dianalisis adalah senyawa yang berkaitan dengan potensi tumbuhan Celosia plumosa dengan analisis pigmen klorofil, karotenoid, dan antosianin. Selain itu, analisis juga dilakukan pada kandungan total flavonoid, fenolik, dan aktivitas antioksidan. Tujuan dari penelitian ini diantaranya untuk mengetahui kandungan pigmen (klorofil, karotenoid, antosianin), flavonoid, fenolik pada tanaman Celosia plumosa bunga merah dan kuning, membandingkan aktivitas antioksidan Celosia plumosa bunga merah dan kuning, dan mengetahui pengaruh kandungan pigmen terhadap aktivitas antioksidan.

\section{METODE PENELITIAN}

Sampel organ Celosia plumosa diambil dari Kopeng, Kabupaten Semarang. Rancangan penelitian menggunakan 2 faktor, pertama Celosia plumosa bunga merah dan kuning, kedua variasi organ yang digunakan adalah organ bunga dan daun. Parameter penelitian yaitu klorofil, karotenoid, antosianin, flavonoid, fenolik, dan aktivitas antioksidan dengan masing-masing dilakukan 3 kali ulangan. Penelitian dilaksanakan pada bulan November hingga Desember 2019 yang bertempat di Laboratorium Biokimia, Fakultas Biologi, Universitas Kristen Satya Wacana, Salatiga

Ekstraksi sampel dilakukan secara maserasi menggunakan etanol pekat selama 48 jam dalam kondisi gelap dan suhu ruang. Sampel yang diambil masing-masing 20 gram dengan 3 ulangan. Sampel yang telah dimaserasi disaring menggunakan kertas saring. Sampel yang telah disaring kemudian dipekatkan hingga $50 \%$ menggunakan rotary evaporator. Sampel lalu disimpan dalam botol plastik dan dimasukkan kedalam kulkas.

Kandungan pigmen klorofil dan karotenoid diukur menggunakan metode spektrofometer dari pustaka Porra et al, 1989. Sampel yang telah diekstrak lalu diukur pada panjang gelombang 649, 664, dan $470 \mathrm{~nm}$. Kandungan pigmen antosianin diukur menggunakan metode $\mathrm{pH}$ diferensial dari pustaka Vina dkk, 2018. Pengujian dengan larutan 
$\mathrm{pH}$ 1,0 dan $\mathrm{pH} 4,5$, sampel yang telah diekstrak lalu diambil sebanyak $1 \mathrm{ml}$ kemudian ditambah dengan 5 $\mathrm{ml}$ larutan vial $\mathrm{pH}$ 1,0 dan untuk diambil sebanyak 1 $\mathrm{ml}$ ekstrak sampel kemudian ditambah dengan $5 \mathrm{ml}$ larutan vial $\mathrm{pH} 4,5$. Nilai absorbansi diukur pada panjang gelombang $700 \mathrm{~nm}$.

Kandungan total flavonoid diukur menggunakan metode $\mathrm{AlCl}_{3}$ (Kolorimetri) dari pustaka John et al (2014). Sampel yang telah diekstrak kemudian diambil sebanyak $1 \mathrm{ml}$ dan dimasukkan dalam tabung reaksi. Larutan lalu ditambah $0,3 \mathrm{ml} \mathrm{NaNO} 25 \%, 0,3 \mathrm{ml} \mathrm{AlCl} 310 \%$ dan $2 \mathrm{ml} \mathrm{NaOH} 1 \mathrm{M}$. Kurva standar yang digunakan adalah kuersetin dengan deret standar $0-100 \mathrm{mg} / \mathrm{l}$. Nilai absorbansi diukur pada panjang gelombang $510 \mathrm{~nm}$. Kandungan fenolik diukur menggunakan metode Folin Ciocalteau dari pustaka Orak (2006). Kurva standar untuk pengujian fenol menggunakan larutan standar asam galat. Pengukuran kandungan total fenol dilakukan dengan mengambil $1 \mathrm{ml}$ ekstak sampel lalu ditambah $1 \mathrm{ml}$ reagen Folin dan $10 \mathrm{ml}$ $\mathrm{Na}_{2} \mathrm{CO}_{3} 7 \%$. Larutan sampel diukur pada panjang gelombang $550 \mathrm{~nm}$.

Pengujian aktivitas antioksidan dilakukan menggunakan metode DPPH. Uji aktivitas antioksidan menggunakan metode DPPH dari pustaka Chan et al, 2007. Larutan DPPH 50 ppm dibuat dengan menimbang $6 \mathrm{mg}$ DPPH lalu dilarutkan dalam $100 \mathrm{ml}$ metanol absolut. Kurva standar yang digunakan menggunakan kuersetin/vitamin C. Sampel dibuat dengan menimbang $6 \mathrm{mg}$ dan dilarutkan dalam metanol absolut hingga volume $100 \mathrm{ml}$. Sampel lalu dibuat dengan rentang konsentrasi $0,001 \mathrm{mg} / \mathrm{ml}-0,1 \mathrm{mg} / \mathrm{ml}$, masing-masing sampel diambil $1 \mathrm{ml}$ lalu ditambah 2 $\mathrm{ml} \mathrm{DPPH}$. Untuk kontrol diambil $1 \mathrm{ml}$ metanol dan $2 \mathrm{ml}$ DPPH. Diinkubasi di tempat gelap selama 30 menit dan diukur pada panjang gelombang $517 \mathrm{~nm}$. Analisis Data dilakukan menggunakan SPSS versi 22 yaitu Correlate

\section{HASIL DAN PEMBAHASAN}

Hasil yang didapatkan pada gambar 1 menujukkan bahwa kadar pigmen klorofil tertinggi ditemukan pada organ daun bunga kuning dapat dilihat bahwa yang memiliki pigmen klorofil tertinggi yaitu pada daun bunga kuning. Dapat diketahui bahwa pada daun bunga kuning penampangannya lebih luas atau bentuknya melebar dibandingkan dengan daun bunga merah yang lebih kecil atau ramping ukurannya. Saiful (2007) menyatakan jumlah klorofil tidak hanya dipengaruhi oleh jumlah pigmennya saja, namun juga dipengaruhi oleh luas permukaan daun. Selanjutnya, ukuran luas daun juga memiliki peran dalam fotosintesis yang terjadi pada daun. Hasil fotosintesis per satuan tanaman ditentukan oleh luas daun. Dengan luas permukaan daun yang lebih besar maka memungkinkan menangkap cahaya yang lebih baik pula sehingga memiliki nilai hasil fotosintesis yang lebih tinggi. Musyarofah dkk. (2006) bahwa kadar klorofil juga dipengaruhi struktur morfologi dan anatomi dari suatu tanaman. Semakin besar ukuran daun suatu tanaman, maka kadar klorofilnya lebih banyak. Begitu pula sebaliknya, semakin kecil ukuran daun suatu tanaman, maka kadar klorofilnya semakin sedikit.

Pigmen karotenoid pada bunga merah, bunga kuning, daun bunga merah, dan daun bunga kuning dapat dilihat (Gambar 2.) bahwa yang memiliki pigmen karotenoid tertinggi yaitu pada bunga merah. Harbelubun et al., (2005) pewarna alami bisa diperoleh dengan cara ekstraksi dari tanaman, dan bagian-bagian tanaman tersebut seperti daun, akar, batang, bunga, kulit, biji, getah, dan buah. Bahan yang menyebabkan warna merah pada bunga, antara lain karena adanya pigmen yang larut antara lain karotenoid. Karotenoid masuk kedalam kelas senyawa isoprenoid yaitu pigmen alami yang memberikan warna kuning ke orange dan merah untuk tanaman. Komposisi karotenoid dalam bunga sangat bervariasi di antara spesies tanaman dan kultivar (Zhu et al; 2010). Namun, pada bunga merah ini dapat mensintesis astaxanthin dalam jumlah tinggi, menghasilkan penampilan warna merah (Cunningham dan Gantt, 2005). Sehingga, pada pengukuran kadar karotenoid ini pada bunga merah lebih tinggi karena masuk kedalam variasi pigmen karotenoid. Pigmen karotenoid sangat bervariasi dari warna kuning sampai warna merah (Sowbhagya and Chitra, 2010).

Pada gambar 3 menunjukkan pada pigmen antosianin pada bunga merah, bunga kuning, daun bunga merah, dan daun bunga kuning dapat dilihat 
bahwa yang memiliki pigmen antosianin tertinggi yaitu bunga merah. Warna merah pada bunga Celosia plumosa disebabkan oleh antosianin yang sama, yakni sianin. Siani pada bunga merah berada dalam bentuk fenol. Warna tertentu yang diberikan oleh suatu antosianin, sebagian bergantung pada $\mathrm{pH}$ bunga. Kemerahan ekstrak bunga Celosia plumosa sangat dipengaruhi oleh konsentrasi antosianin. Pada pigmen antosianin yang terekstrak memiliki kecenderungan berwarna pekat, sehingga pada bunga merah akan menghasilkan warna yang lebih pekat. Pada konsentrasi antosianin yang tinggi, intensitas warnanya juga tinggi dan jika terjadi penurunan konsentrasi antosianin, intensitas merahnya juga menurun diiringi dengan meningkatnya nilai kecerahan (Jordheim, 2007).

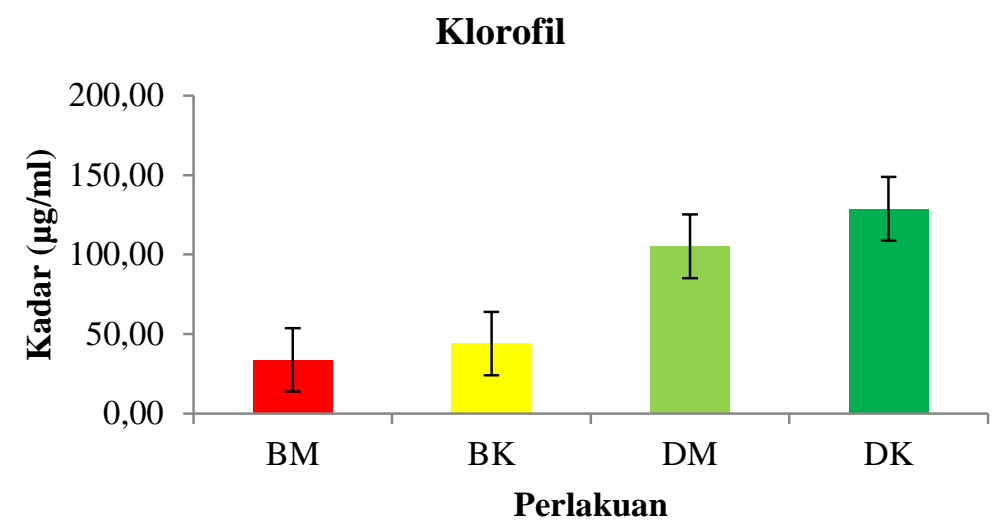

Gambar 1. Kadar Pigmen Klorofil pada Bunga Merah, Bunga Kuning, Daun Bunga Merah, dan Daun Bunga Kuning

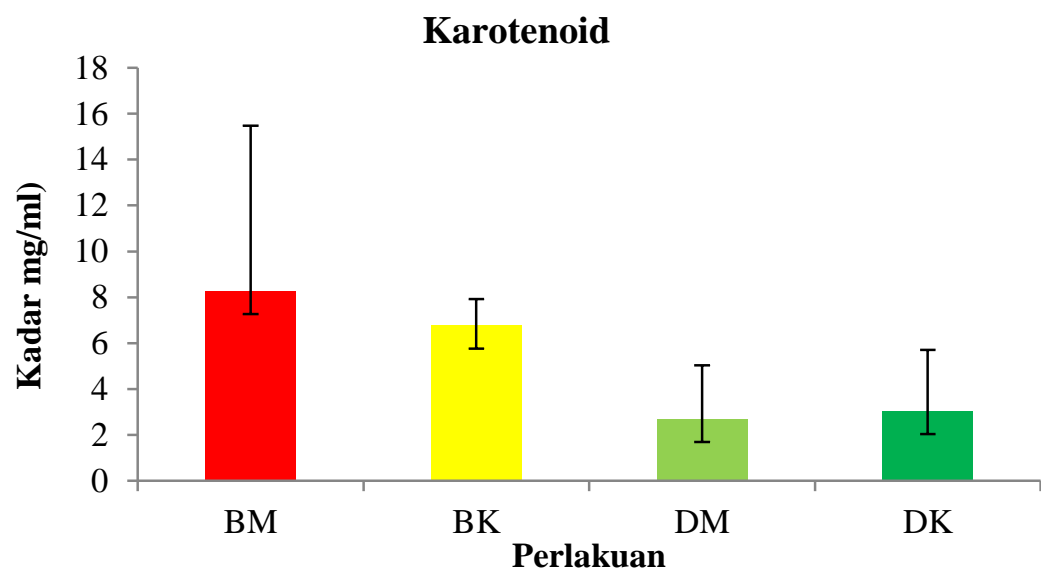

Gambar 2. Kadar Pigmen Karotenoid pada Bunga Merah, Bunga Kuning, Daun Bunga Merah, dan Daun Bunga Kuning

Kadar flavonoid pada bunga merah, bunga kuning, daun bunga merah, dan daun bunga kuning (Gambar 4.) menunjukkan bahwa kadar flavonoid tertinggi terdapat pada organ bunga berwarna merah. Flavonoid merupakan suatu kelompok senyawa fenol yang terbesar ditemukan dialam. Senyawasenyawa ini merupakan zat warna merah, ungu, biru, dan kuning yang ditemukan dalam tumbuhtumbuhan. Produksi flavonoid total sangat berhubungan dengan pigmen warna pada tanaman (Ghasemzadeh et al.,2010). Kandungan flavonoid pada bunga merah Celosia plumosa lebih tinggi, hal tersebut diduga karena pada bunga merah banyak mengandung antosianin,yaitu pigmen utama sebagai penyusun warna merah (Wang et al., 2009). Zhao et al. (2012) menyatakan flavonoid total terdiri atas unsur antosianin sebagai kelompok utama serta gabungan dari chalcones dan anthoxanthine. 
Ghasemzedah et al. (2010) menyatakan beberapa produk dari biosintesis kelompok fenol pada tanaman seperti antosianin dirubah menjadi flavonoid, sehingga pada bunga Celosia plumosa warna merah kandungan flavonoidnya lebih tinggi.

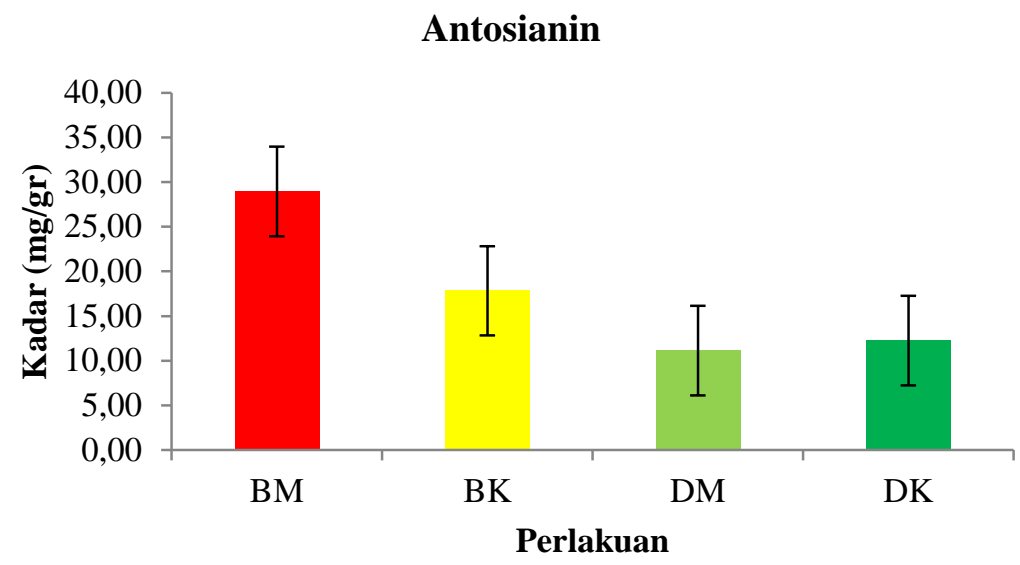

Gambar 3. Kadar Pigmen Antosianin pada Bunga Merah, Bunga Kuning, Daun Bunga Merah, dan Daun Bunga Kuning

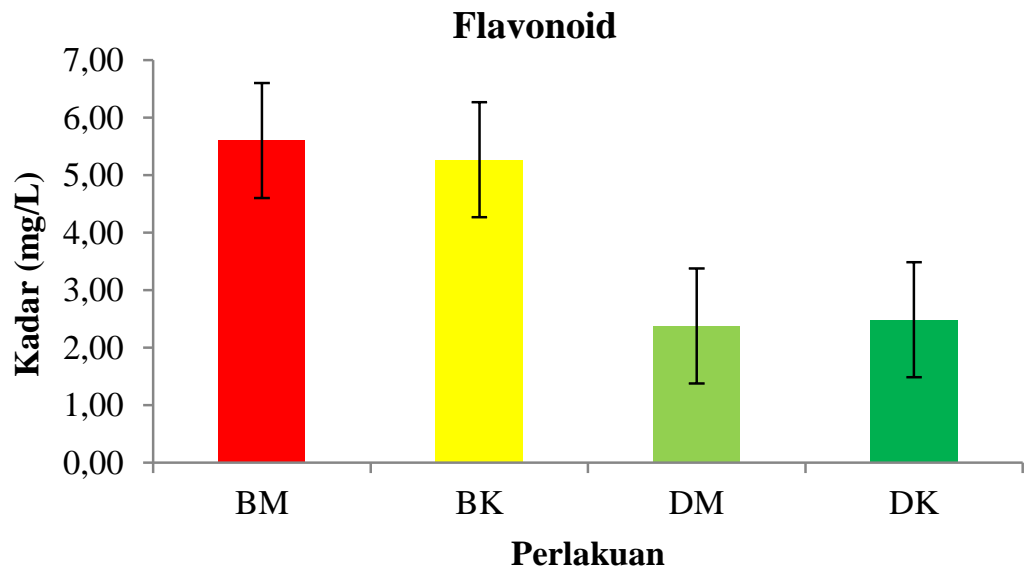

Gambar 4. Kadar Flavonoid pada Bunga Merah, Bunga Kuning, Daun Bunga Merah, dan Daun Bunga Kuning

Berdasarkan gambar 5 menunjukkan bahwa kadar fenolik pada bunga merah, bunga kuning, daun bunga merah, dan daun bunga kuning yang memiliki kadar fenolik paling tinggi yaitu bunga merah. Penetapan kadar fenolik total dilakukan dengan menggunakan pereaksi Folin-Ciocalteau. Reagen Folin Ciocalteau digunakan karena senyawa fenolik dapat bereaksi dengan Folin membentuk larutan berwarna yang dapat diukur absorbansinya. Kadar fenolik total pada bunga merah lebih besar dibandingkan dengan lainnya. Perbedaan variasi warna bunga berhubungan juga dengan kadar fenolik total. Menurut Sirait (2007), antosianin pelargonidin dan sianidin memberikan warna merah, sehingga menghasilkan fenolik yang tinggi. Dengan melihat kadar fenolik total yang terkandung dalam ekstrak bunga merah yang tinggi maka dapat diperkirakan besar aktivitas antioksidannya.

Gambar 6 merupakan nilai $\mathrm{IC}_{50}$ dari bunga merah, bunga kuning, daun bunga merah, dan daun bunga kuning dapat dilihat yang memiliki nilai $\mathrm{IC}_{50}$ yang paling kuat dan tinggi ditemukan pada bunga merah. Metode uji menggunakan DDPH ini didasarkan pada penurunan absorbansi akibat perubahan warna larutan warna DPPH, dimana DPPH akan bereaksi dengan atom hidrogen dari 
senyawa peredam radikal bebas membentuk DPPH Hidrazin yang lebih stabil. Uji antioksidan dalam penelitian ini menggunakan parameter $\mathrm{IC}_{50}$ (Inhibition Concentration) untuk menginterpretasikan hasil pengujian dengan metode uji menggunakan DPPH. $\mathrm{IC}_{50}$ merupakan nilai yang menunjukkan kemampuan penghambatan 50\% radikal bebas oleh suatu konsentrasi sampel (ppm) (Mailandari, 2012). Semakin kecil nilai $\mathrm{IC}_{50}$ berarti semakin tinggi aktivitas antioksidan. Jika nilai $\mathrm{IC}_{50}$ suatu ekstrak berada dibawah 50 ppm maka aktivitas antioksidannya sangat kuat, nilai $\mathrm{IC}_{50}$ berada diantara 50-100 ppm berarti aktivitas antioksidannya kuat, nilai $\mathrm{IC}_{50}$ berada di antara $100-150$ ppm berarti aktivitas antioksidannya sedang, nilai $\mathrm{IC}_{50}$ berada di antara 150-200 ppm berarti aktivitas antioksidannya lemah, sedangkan apabila nilai $\mathrm{IC}_{50}$ berada diatas 200 ppm maka aktivitas antioksidannya sangat lemah (Molyneux, 2004). Hasil perhitungan akhir menunjukkan nilai $\mathrm{IC}_{50}$ untuk ekstrak bunga merah mempunyai $\mathrm{IC}_{50}$ sebesar $2,75 \mathrm{ppm}$, untuk ekstrak bunga kuning sebesar 10,87 ppm, untuk ekstrak daun bunga merah sebesar 2,83 ppm sedangkan nilai $\mathrm{IC}_{50}$ pada daun bunga kuning sebesar 10,13 ppm. Hal ini menjelaskan bahwa kemampuan menangkap radikal bebas ekstrak Celosia plumosa bunga warna merah dan kuning dengan variasi organ bunga dan daun termasuk dalam golongan kategori sangat kuat dikarenakan nilai $\mathrm{IC}_{50}$ hasil perhitungan kurang dari $50 \mathrm{ppm}$, dari keempat perlakuan yang memiliki nilai $\mathrm{IC}_{50}$ tertinggi adalah bunga merah. Pada nilai $\mathrm{IC}_{50}$ diketahui bahwa semakin rendah menunjukkan penghambatan radikal bebas yang lebih kuat. Perbedaan aktivitas antioksidan yang berbeda dikarenakan oleh adanya perbedaan konsentrasi dari metabolit sekunder (Shahabimajd, 2006).

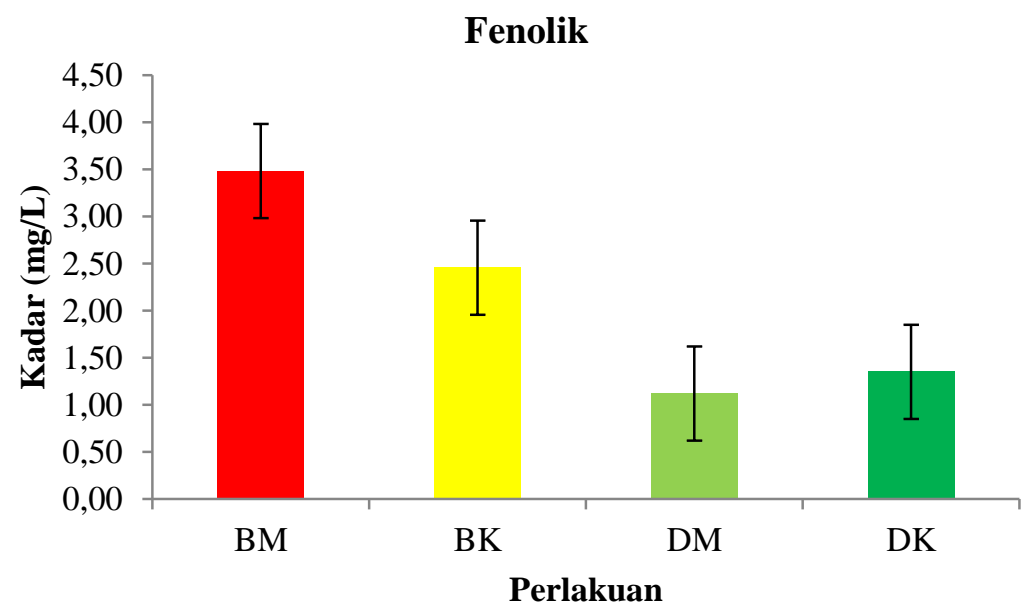

Gambar 5. Kadar Fenolik pada Bunga Merah, Bunga Kuning, Daun Bunga Merah, dan Daun Bunga Kuning

Hubungan korelasi antara pigmen dan metabolit sekunder pada bunga merah terdapat korelasi antara karotenoid dengan flavonoid (Tabel 1.) memiliki nilai ( $\mathrm{p}$ value $0.041<\alpha 0.05$ ), dengan nilai korelasi 0.998 yang memiliki nilai korelasi positif, apabila nilai karotenoid naik, maka flavonoid akan naik, dan sebaliknya. Nilai korelasi positif menunjukkan korelasi yang kuat karena semakin mendekati 1, maka korelasi dianggap semakin kuat. Salah satu tanaman yang mengandung flavonoid yaitu bunga merah. Sulastri et al. (2013) melaporkan bunga merah mengandung flavonoid. Pada uji karotenoid menggunakan pelarut etanol, pelarut yang bersifat polar dapat mengikat komponen senyawa fenolik termasuk flavonoid dan karotenoid. Pigmen karotenoid dengan flavonoid dapat berkorelasi positif karena sifat kepolarannya. Flavonoid dan karotenoid mempunyai sifat non polar, karotenoid yang dihasilkan akan menempel dan apabila warna yang dihasilkan semakin merah, maka kandungan flavonoid lebih tinggi. Flavonoid mempunyai kepolaran yang berbeda tergantung dari jumlah dan posisi gugus hidroksil tiap jenis flavonoid sehingga hal tersebut akan mempengaruhi kelarutan flavonoid pada pelarut (Harborne, 1996). Menurut Melia dkk (2018), total flavonoid pada ekstrak C.plumosa dengan pelarut etanol menunjukkan bahwa pelarut etanol memiliki tingkat 
kepolaran yang menyerupai dan lebih efektif dalam melarutkan senyawa pada karotenoid dan menghasilkan senyawa flavonoid yang juga tinggi. Serta dapat dipengaruhi oleh efek paparan cahaya yaitu pigmen karotenoid tinggi daripada pigmen klorofil. Kandungan flavonoid memiliki korelasi positif dengan kandungan karotenoid, karena mereka memiliki kandungan flavonoid dan karotenoid yang tinggi secara bersamaan (Kim et al., 2010).

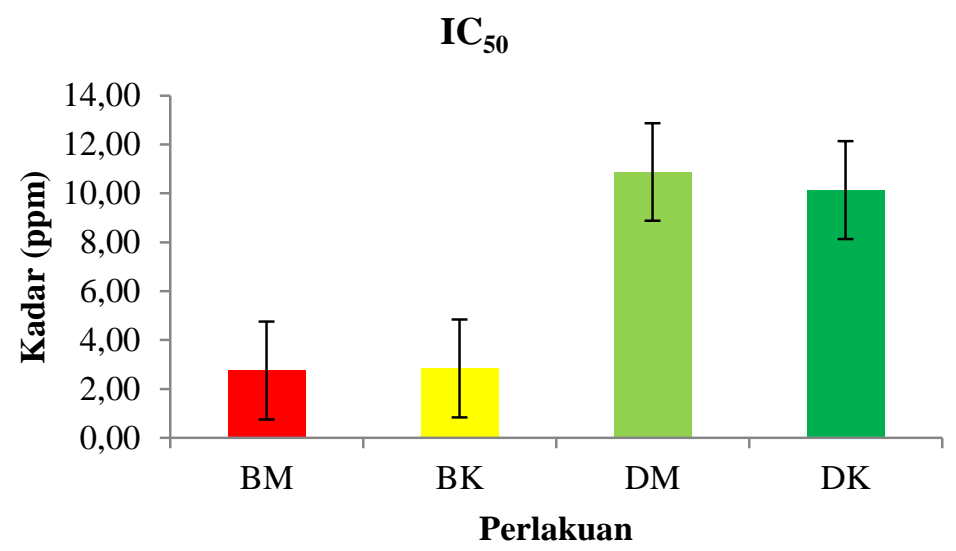

Gambar 6. Nilai IC $_{50}$ pada Bunga Merah, Bunga Kuning, Daun Bunga Merah, dan Daun Bunga Kuning

Tabel 1. Korelasi kandungan pigmen dan metabolit sekunder pada bunga merah menunjukkan adanya hubungan korelasi positif antara pigmen karotenoid dengan flavonoid.

\begin{tabular}{|c|c|c|c|c|c|}
\hline & & & \multicolumn{3}{|c|}{ Pigmen } \\
\hline & & & Antosianin & Klorofil & Karotenoid \\
\hline \multirow{4}{*}{$\begin{array}{l}\text { Metabolit } \\
\text { Sekunder }\end{array}$} & \multirow[t]{2}{*}{ Flavonoid } & $\begin{array}{l}\text { Pearson } \\
\text { Correlation }\end{array}$ & .057 & .702 & .998 \\
\hline & & Sig. (2-tailed) & .964 & .505 & .041 \\
\hline & \multirow[t]{2}{*}{ Fenolik } & $\begin{array}{l}\text { Pearson } \\
\text { Correlation }\end{array}$ & .539 & .263 & .838 \\
\hline & & Sig. (2-tailed) & .638 & .831 & .367 \\
\hline
\end{tabular}

Tabel 2. Korelasi kandungan pigmen dan metabolit sekunder pada bunga kuning tidak menunjukkan adanya hubungan korelasi.

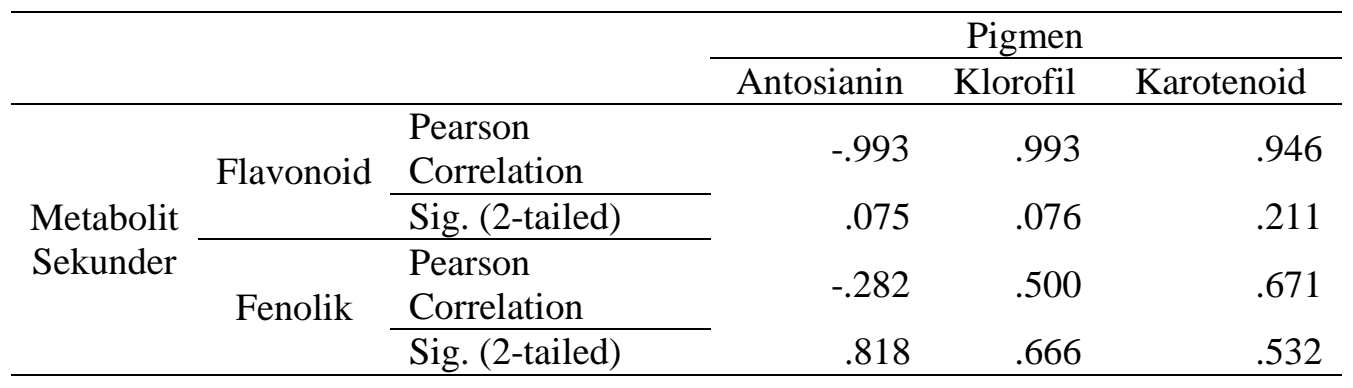

Hubungan korelasi pada (Tabel 2.) menunjukkan bahwa bunga kuning tidak terdapat korelasi antara pigmen dan metabolit sekunder. Hal ini dikarena nilai korelasi yang didapatkan $\mathrm{p}>\alpha$ 0.05 , sehingga tidak terdapat hubungan korelasi. Serta pada (Tabel 3.) hubungan korelasi pada daun bunga merah tidak terdapat korelasi antara pigmen dan metabolit sekunder. Hal ini dikarena nilai korelasi yang didapatkan $p>\alpha 0.05$, sehingga tidak terdapat hubungan korelasi.

Pada Tabel 4. hubungan korelasi daun bunga kuning terdapat korelasi antara antosianin dengan 
flavonoid memiliki nilai ( $\mathrm{p}$ value $0.002<\alpha 0.05$ ), dengan nilai korelasi 1.000 yang memiliki nilai korelasi positif, apabila nilai antosianin naik, maka flavonoid akan naik, dan sebaliknya. Nilai korelasi positif menunjukkan korelasi yang kuat karena semakin mendekati 1, maka korelasi dianggap semakin kuat. Adanya korelasi yang positif dan sangat kuat karena antosianin termasuk pigmen kelompok flavonoid yanga menghasilkan warna jingga, merah, dan biru bersifat larut dalam air dan mudah mengalami degradasi (Hardoko et al., 2010). Zhao et al. (2012) menyatakan flavonoid total terdiri atas unsur antosianin sebagai kelompok utama serta gabungan dari chalcones dan anthoxanthine.

Tabel 3. Korelasi kandungan pigmen dan metabolit sekunder pada daun bunga merah tidak menunjukkan adanya hubungan korelasi.

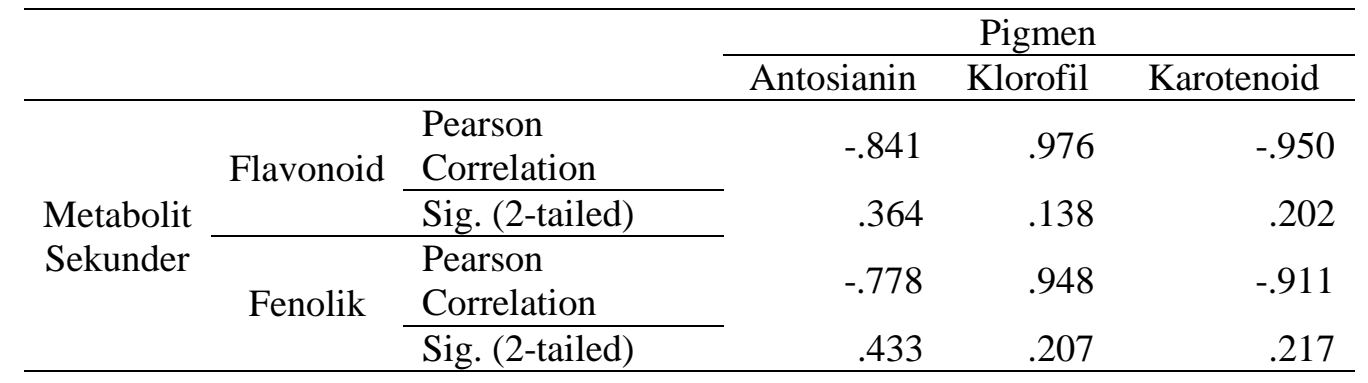

Tabel 4. Korelasi kandungan pigmen dan metabolit sekunder pada daun bunga kuning menunjukkan adanya hubungan korelasi positif yang kuat antara pigmen antosianin dengan flavonoid.

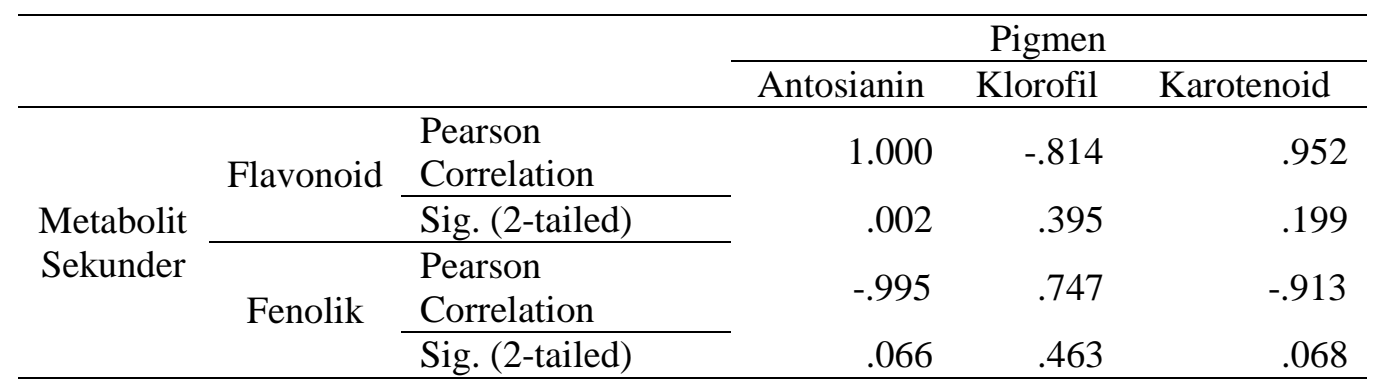

\section{KESIMPULAN}

Berdasarkan penelitian yang telah dilakukan, dapat disimpulkan jika kandungan pigmen (antosianin, klorofil, dan karotenoid) berpengaruh terhadap aktivitas antioksidan. Terdapat korelasi positif antara pigmen karotenoid dengan flavonoid. Sedangkan flavonoid dan pigmen pada daun bunga kuning dan daun bunga merah menunjukkan tidak adanya hubungan korelasi

\section{DAFTAR PUSTAKA}

Aparna Srinivasan, K.R. Rajadurai, S.P. Thamarai Selvi and P.Jeyakumar. 2017. Effect of Pigments, Phenol Content and Postharvest Life on Application of Plant Growth Retardants in Celosia Spp. Chem Sci Rev Lett. 6(23), 1769-1772.
Boijan, B., S.E. Clemants, T. Borsch. 2013. Amaranthaceae. In Z.Y. Wu, P.H. Raven, D.Y. Hong (Eds).Flora of China, (Ulmaceae through Basellaceae). Science Press.

Chan, E. W. C., Lim, Y.Y. and Omar, M. 2007. Antioxidant and Antibacterial Activity of Leaves of Etlingera species (Zingiberaceae) in Peninsular Malaysia. Food Chemistry. 104 (4) : 1586-1593.

Cunningham FX and Gantt E. 2005. A study in scarlet: biosynthesis of ketocarotenoids in the flowers of Adonis aestivalis.Plant $\mathrm{J}$ 41:478-492.

Elka Yulislinda, dkk. 2012. Penentuan Aktivitas Antioksidan dari Berbagai Ekstrak Sayursayuran Segar dan Dikukus dengan Metode DPPH, Padang: FFUA. 
Ghasemzadeh, A., H.Z.E. Jaafar, A. Rahmat, P.E.M. Wahab, M.R.A. Halim. 2010. Effect of different light intensities on total phenolics and flavonoids synthesis and anti-oxidant activities in young ginger varieties (Zingiber officinale Roscoe). Int. J. Mol. Sci. 11(10): 3885-3897.

G H Urmila, B. Ganga Rao, T. Satyanarayana. 2013. Phytochemical And In-Vitro Antioxidant Activity of Methanolic Extract of Lactuca scariola and Celosia argantea Leaves. Journal of Drug Delivery \& Therapeutics. 3(4), 114-117.

Giorgio, P., 2000. Flavonoid as Antioxidant. Journal National Product. 63: 1035-1045.

Harbelubun AE, Kesaulija EM, dan Rahawarin YY. 2005. Tumbuhan Pewarna Alami dan Pemanfaatannya Secara Tradisional oleh Suku Marori Men-Gey di Taman Nasional Wasur Kabupaten Merauke. Biodiversitas. 6(4),281-284.

Harborne, J.B. 1996. Metode Fitokimia: Penuntun Cara Modern Menganalisis Tumbuhan. ITB Press, Bandung.

Hardoko, Hendarto L, Siregar TM. 2010. Pemanfaatan Ubi Jalar Ungu (Ipomoea batatas L.Poir) sebagai Pengganti Sebagian Tepung Terigu dan Sumber Antiokisdsan pada Roti Tawar. Jteknol dan Industri Pangan. 21(1): 25.

John, Biju., Sulaiman C, Satheesh, George., V.R.K. Reddy. 2014. Total Phenolic and Flavonoids in Selected Medicinal Plants from Kerala. International Journal of Pharmacy and Pharmaceutical Sciences. 6(1), 406-408.

Jordheim, Monica. 2007.Isolation,Identification and Properties of Pyranoanthocyanins and Athocyanin Forms. Norway: University of Bergen.

Kim JK, Lee SY, Chu SM, Lim SH, Suh SC, Lee YT, Cho HS, Ha SH. 2010. Variation and Correlation analysis of flavonoids and carotenoids in Korean pigmented rice (Oryza sativa L.) cultivars. J Agric Food Chem. 22;58(24)12804-9.
Mailandari, M. 2012. Uji aktivitas antioksidan ekstrak daun garcinia kydia roxb. dengan metode DPPH dan identifikasi senyawa kimia fraksi yang aktif. Depok, Universitas Indonesia.

Mastuti R., Arumningtyas E.L. dan Fatinah A.A. 2013. Profile of some celosia variants in East Java, Indonesia.

Mastuti R., Cai Y. dan Corke H. 2010. Identifikasi pigmen betasianin paada jenis inflorescene Celosia. Seminar Biologi, Yogyakarta.

Mastuti, R., E.L. Arumningtyas, A.A. Fatinah. 2015. Genetic diversity of Celosia variants in East Java based on polyphenol oxidasePPO Genes. Procedia Chemistry. 14 : 361366.

Melia Verdiana, I Wayan Rai Widarta, I Dewa Gede Mayun Permana. 2018. Pengaruh jenis pelarut pada ekstraksi menggunakan gelombang ultrasonik terhadap aktivitas antioksidan ekstrak kulit buah lemon (Citrsu limon (Linn.) Burm F.). Jurnal Ilmu dan Teknologi Pangan. 7(4), 213-222.

Molyneux, P. 2004. The use of the stable free radical diphenylpicrylhydrazyl (DPPH) for estimating antioxidant activity. Journal of Science Technology. 26(2), 211-219.

Musyarofah, N., S. Susanto, S.A. Aziz, S. Kartosoewarno. 2006. Respon Tanaman Pegagan (Centella asiatica L. Urban) Terhadap Pemberian Pupuk Alami di Bawah Naungan. Seminar Sekolah Pasca Sarjana Institut Pertanian Bogor. Bogor.

National Research Council. 2006. Lost Crops of Africa Vegetables.The National Academies Press, Washington, US.

Orak H. 2006. Total antioxidant activities, phenolics, anthocyanins, polyphenoloxidase activities in red grape varieties. Electronic Journal of Polish Agricultural University Food Science and Technology. 9: I17 - 118.

Porra, R. J., Thompson W. A. and Kriedemann P.E., 1989. Determination of accurate extinction coefficients and simultaneous equations for assaying chlorophylls $a$ and $b$ 
extracted with four different solvents: verification of the concentration of chlorophyll standards by atomic absorption spectrometry, Biochim. Biophys. Acta, 975(3), 384-394.

Qusti SY, Abo-khatwa AN, Bin Lahwa MA. 2010. Screening of antioxidant activity and phenolic content of selected food items cited in the holly Quran. EJBS.

Rajalakshmi, D dan Narasimhan, S. 1985. Food Antioxidants: Sources and Methods of Evaluation. In D.L. Madhavi: Food Antioxidant, Technological, Toxilogical and Health Persperctives. Marcel Dekker Inc. Hongkong: 76-77.

Sadegh Mohajer*, Rosna Mat Taha, Arash Khorasani Esmaeili, Noraini Mahmad and Normadiha Mohamed. 2013. Anthocyanin Production, Antioxidant Potential and Antitumor Activity of Celosia cristata againt HCR 116 Cell Line. Full Paper Proceeding. Vol.1, 330-337.

Saiful, 2007. Klorofil Diktat Kuliah Kapita Selekta Kimia Organik. Lampung: Universitas Lampung

Shahabimajd, N. 2006. Antioxidant activity, phenol and flavonoid contents of some selected iranian medicinal plants. African journal of Biotechnology. 5(11), 11421145 .

Sirait, M., 2007, Penuntun Fitokimia dalam Farmasi. Bandung: ITB Press.

Sowbhagya, HB. and Chitra, VN. 2010. EnzymeAssisted Extraction of Flavorings and Colorants from Plant Materials. Critical Review in Food Science and Nutrion.Taylor and Francis Group, LLC, 50(2): 146-161.

Sulastri, Eerlidawati, Syahrial, Nazar, M. Dan Andayani, T. 2013. Aktivitas Antioksidan Ekstrak Daun Ubi Jalur Ungu (Ipomea batatas L.) Hasil Budidaya Daerah Saree Aceh Besar. Jurnal Rekayasa Kimia dan Lingkungan. 9(3): 126-131.

Velu, I., Ravi, A., Gopalakrishnan, D., Manivannan, B., Sathiavelu, M., Arunachalam, S. 2012. Comparison antioxidant activity ant total phenolic of Amaranthus tritis and Celosia argantea var spicata. Asian pasific journal of tropical biomedicine. 1-4.

Vina Juliana Anggraeni, Liska Ramdanawati, Winda Ayuantika. 2018. Penetapan Kadar Antosianin Total Beras Merah (Orzya nivara). Jurnal Kartika Kimia. 1(1), 11-16.

Wang, S.Y., C.T. Chen, C.Y. Wang. 2009. The influence of light and maturity on fruit quality and flavonoid content of red raspberries. Food Chem. 112(3), 676-684.

Zhao, D., J. Tao, C. Han, J. Ge. 2012. Flower color diversity revealed by differential expression of flavonoid biosynthetic genes and flavonoid accumulation inherbaceous peony (Paeonia lactiflora Pall.). Mol. Biol. Rep. 39(12), 11263-11275.

Zhu C, Bai C, Sanahuja G, Yuan D, Farré G, Naqvi S, Shi L, Capell T, Christou P. 2010. The regulation of carotenoid pigmentation in flowers. Arch Biochem Biophys. 1;504(1):132-41. 